\title{
Cytologic evaluation of endometrial stromal sarcoma using imprint smears
}

\author{
- A case report - \\ 1) Department of Pathology, Kagawa Medical School, Miki Kagawa, ${ }^{2)}$ Department of \\ Pathology, Osaka Kaisei Hospital, Osaka \\ Masanao OKADA ${ }^{1)}$, Yasuko SAKAMOTO ${ }^{2)}$, Kazuo MIYAMOTO ${ }^{1)}$ \\ and Mitsuya HONDA $^{2)}$
}

59 歳の女性. 性器出血のために, 内膜生検をして低分化腺癌と診断された．摘出子宮は小児頭大 で， 2 個の筋腫と長径 $8 \mathrm{~cm}$ の腫演があり，中心壞死に陥り，子宮内腔に破綻しているが，漿膜を 侵していない. 腫瘍は組織学的に, 大形多角形均一な細胞からなり，類円形の核を持つ. 腫瘍細胞 は㖪様にあるいは敷石状に，また索状に配列する。強拡大 10 視野中に約 25 個の核分裂像がみら れ，悪性度は高い，捺印パパニコロウ染色標本の細胞学的所見. 腫瘍細胞は孤立性に存在するもの が多く, 細胞形は円形ないし棈円形で, N/C 比は高く胞体は乏しい. 細胞質は淡青色に染色され, 胞体緣は不明膫で，胞体がしばしば透明である．胞体がやや豊富で好塩基性に強く染色され，核が 偏在する細胞が少数みられる. 核の面積は $251 \mu^{2}$ で, 対照の間質細胞（3 例の分泌期末期内膜） の核 138〜178 $\mu^{2}$ に比べて有意に大きい，核形は円形から棈円形で，核縁は平滑で明膫である，紡 錘形, 桿状, 彎曲あるいは 2 分葉化した核が少数ある. 核クロマチンは軽度増量し, 細顆粒状ない し粗顆粒状である. 核小体は顕著ではないが， 1 個から 3 個ある. 電子顕微鏡的に細胞間接着装置 が少数みられ，また胞体内に細線維があり，まれにはそれらが細線維性の球状体として観察され る.

Key words : Uterine corpus—Sarcoma—Undifferentiated carcinoma

\section{Introduction}

The endometrial stromal sarcoma is a rare malig-

Cytologic evaluation of endometrial stromal sarcoma using imprint smears — A case report -

Masanao OKADA, M.D., Kazuo MIYAMOTO, M.D. Department of Pathology, Kagawa Medical School, Miki Kagawa, Japan

Yasuko SAKAMOTO, C.T., J.S.C. and Mitsuya HONDA, M.D.

Department of Pathology, Osaka Kaisei Hospital, Osaka 論文別刷請求先 画761-07 香川県木田郡三木町大字池戸

1,750 の 1 香川医科大学病理 岡田正直

昭和 58 年 5 月 11 日受付

昭和 59 年 8 月 3 日受理 nant tumor that is to be differentiated from the poorly differentiated carcinoma and other sarcomas. We present the cytological findings obtained from imprint smear of a endometrial stromal sarcoma that was diagnosed as a poorly differentiated carcinoma following preoperative biopsy.

\section{Case report}

A 59-year-old nullipara woman complaining of irregular genital bleeding for 6 months was sent to the Center for Adult Diseases in Osaka with a clinical diagnosis of a myoma uteri. Endometrial biopsy 
revealed a poorly differentiated adenocarcinoma. The woman was admitted to the Osaka Kaisei hospital for an operation. A total hysterectomy and bilateral salpingo-oophorectomy was performed. No postoperative treatment such as chemotherapy or irradiation followed. The patient was well as of April 1983, twenty months after the operation.

\section{Materials and Procedures}

Imprint smears were prepared from the cut surface of the resected tumor. Papanicoloau stain and PAS staining reactions were performed on imprint smears. Histological examinations were made on resected tumor blocks using Hematoxylin-PhloxineSaffron (HPS), Periodic acid-Schiff (PAS), AzanMallory and silver impregnation. Specimens for the ultrastructural examination were prepared from blocks fixed in $10 \%$ formalin.

\section{Pathological findings}

The gross: The resected uterus was occupied with an irregular shaped and hard tumor (Fig. 1). Two nodules of the leiomyoma were found in the uterine posterior wall. The tumor with a central necrosis adjacent to the leiomyoma, was located in the uterine posterior wall and fundus. The tumor demarcated from the myometrium almost completely, without any serosal infiltration.

Cytological features: In vaginal pool-smear before the surgery, atypical cells were not noted. In the imprint smear, the tumor diathesis was absent, most tumor cells appeared singly (Fig. 6), but sometimes in small clusters (Fig. 5, 7). The tumor cells were round or elliptical with slight anisocytosis and anisokaryosis. The N/C ratio was high with scant cytoplasm and the cytoplasm stains slightly cyanophilic without distinct cytoplasmic margins. Sometimes the cytoplasm appeared transparent. Occasionally tumor cells were found with more abundant basophilic cytoplasm and eccentric nuclei (Fig. 7). The nuclear shape in most tumor cells was round or ovoid with smooth and distinct nuclear margins. Some nuclei had nipple-like projections or notched margins (Fig. 8). In rare cases the nuclei resembled spindle-shaped, rod-shaped, bi-lobed or bizarre giant forms (Fig. 9). The evenly distributed nuclear chromatin was increased slightly and fine granular (Fig. $6,7)$. The nuclear area was $251 \pm 74 \mu^{2}$, significantly larger than endometrial stromal cells of three control cases of the late secretory endometrium (measuring $138 \pm 34 \mu^{2}, 144 \pm 48 \mu^{2}$ and $178 \pm 47 \mu^{2}$ ). In general, nucleoli were not so prominent, while tumor cells with one to three small nucleoli were sometimes observed. In the smear, mitotic figures and multinucleated giant cells were not found. Tumor cells showed a negative reaction for PAS.

Histological features indicated that the tumor tissue proliferated and spread, with negligible myometrial invasion. The tissue showed an uneven alveolar pattern, and was composed of uniform large ovoid or partially spindle-shaped cells proliferating in a trabecula-like manner (Fig. 2). The tumor tissue appeared compact, but the intercellular bridges and organoid structures lacked. In higher magnification, small clusters of tumor cells were observed sporadically but no characteristic structures were seen. The N/C ratio of the tumor cells was high and the nucleus of the cell appeared vesicular with small nucleoli. In HPS preparations the cytoplasm stained slightly pink and the cytoplasmic border was distinct. The mitotic rate was elevated high being 25 mitoses per 10 high power fields (Fig. 3). The reticulin fibers did not surround individual tumor cells (Fig. 4). Lysozyme and myoglobin were not detected in tumor cell by the PAP method.

Electron-microscopy showed rounded or indented nuclei of tumor cells with a smooth contour. Nucleoli were not prominent. The cytoplasmic volume was moderate or relatively scant with obscure endoplasmic reticulum because of the autolysis and rather abundant mitochondria. Rarely desmosome-like junctions were observed (Fig. 10). In cytoplasm of some tumor cells microfilaments were present and in few cells, the microfilaments aggregated forming a cytoplasmic sphere (Fig. 11). Microvilli were absent. 
Table 1 Cytological features of endometrial stromal sarcoma and tumors to be differentiated from it

\begin{tabular}{|c|c|c|c|c|c|c|}
\hline & $\begin{array}{l}\text { undifferentiated } \\
\text { carcinoma }\end{array}$ & leiomyosarcoma & $\begin{array}{l}\text { endometrial } \\
\text { stromal } \\
\text { sarcoma }\end{array}$ & $\begin{array}{l}\text { mesodermal } \\
\text { mixed } \\
\text { tumor }\end{array}$ & lymphoma & leukemia \\
\hline Cell arrangement & $\begin{array}{l}\text { single or in } \\
\text { small } \\
\text { cluster }\end{array}$ & $\begin{array}{l}\text { single or in } \\
\text { small } \\
\text { cluster }\end{array}$ & $\begin{array}{l}\text { single or in } \\
\text { small } \\
\text { cluster }\end{array}$ & $\begin{array}{l}\text { single } \\
\text { and } \\
\text { in cluster }\end{array}$ & single & single \\
\hline $\begin{array}{c}\text { Cytoplasm } \\
\text { Shape }\end{array}$ & $\begin{array}{l}\text { round or } \\
\text { oval }\end{array}$ & spindle & spindle & $\begin{array}{l}\text { spindle or } \\
\text { pleomorphic }\end{array}$ & $\begin{array}{l}\text { round or } \\
\text { oval }\end{array}$ & $\begin{array}{l}\text { round or } \\
\text { oval }\end{array}$ \\
\hline $\mathrm{N} /$ Cratio & high & high & high & high or low & high & high \\
\hline $\begin{array}{l}\text { Cellular } \\
\text { border }\end{array}$ & ill-defined & ill-defined & ill-defined & $\begin{array}{l}\text { distinct or } \\
\text { ill-defined }\end{array}$ & ill-defined & ill-defined \\
\hline $\begin{array}{l}\text { Staining to } \\
\text { light green }\end{array}$ & well stained & faint & faint & $\begin{array}{l}\text { faint or well } \\
\text { stained }\end{array}$ & $\begin{array}{l}\text { well } \\
\text { stained }\end{array}$ & $\begin{array}{l}\text { well } \\
\text { stained }\end{array}$ \\
\hline Polymorphism & moderate & slight & slight & marked & slight & slight \\
\hline $\begin{array}{c}\text { Nucleus } \\
\text { Shape }\end{array}$ & round or oval & $\begin{array}{l}\text { oval or } \\
\text { spindle }\end{array}$ & $\begin{array}{l}\text { spheroidal } \\
\text { or } \\
\text { spindle }\end{array}$ & $\begin{array}{l}\text { spindle or } \\
\text { irregular }\end{array}$ & oval & oval \\
\hline Chromatin & coarse & fine & fine & spindle or & oval & oval \\
\hline $\begin{array}{l}\text { Chromatin } \\
\text { Polymorphism }\end{array}$ & $\begin{array}{l}\text { granular } \\
\text { coarse } \\
\text { granular } \\
\text { moderate }\end{array}$ & $\begin{array}{l}\text { garnular } \\
\text { fine } \\
\text { granular } \\
\text { slight }\end{array}$ & $\begin{array}{l}\text { granular } \\
\text { fine } \\
\text { granular } \\
\text { slight }\end{array}$ & $\begin{array}{l}\text { irregular } \\
\text { fine or } \\
\text { condensed } \\
\text { marked }\end{array}$ & $\begin{array}{l}\text { granular } \\
\text { slight }\end{array}$ & $\begin{array}{l}\text { fine } \\
\text { granular } \\
\text { slight }\end{array}$ \\
\hline Nucleolus & $\begin{array}{l}\text { noted } \\
\text { sometimes }\end{array}$ & $\begin{array}{l}\text { noted } \\
\text { sometimes }\end{array}$ & $\begin{array}{l}\text { noted } \\
\text { sometimes }\end{array}$ & prominent & noted & prominent \\
\hline $\begin{array}{l}\text { Multinucleated } \\
\text { cell }\end{array}$ & not noted & not noted & not noted & noted & not noted & $\begin{array}{l}\text { not } \\
\text { noted }\end{array}$ \\
\hline Giant cell & not noted & $\begin{array}{l}\text { noted } \\
\text { sometimes }\end{array}$ & $\begin{array}{l}\text { not } \\
\text { noted }\end{array}$ & noted & $\begin{array}{l}\text { not } \\
\text { noted }\end{array}$ & $\begin{array}{l}\text { not } \\
\text { noted }\end{array}$ \\
\hline
\end{tabular}

\section{Discussion}

Presently there are no definite criteria for the diagnosis of endometrial stromal sarcoma. In general, the endometrial stromal sarcoma rarely sheds cells and its tumor cells are indistinguishable from leiomyosarcoma cells ${ }^{9,10)}$. Hsiu and Stawicki ${ }^{6)}$ summarized the cytologic features : (1) isolated tumor cells, (2) uniform pattern of tumor cells in spite of marked nuclear variations, (3) "comet" appearance of tumor cells, (4) presence of bizarre, multinucleated giant tumor cells based on the cytologic finding of cervical smears in two cases of stromal sarcoma. Höffken et al. ${ }^{5)}$ reported the cytomorphological finding of endocervical smears in two cases : (1) clumping of tumor cells, (2) relatively monomorphous pattern with few variations in size and shape of nuclei, (3) irregular distribution of nuclear chromatin with coarsely granular clumping and thickening of nuclear rim, (4) occasional occur- rences of two or more macronucleoli, (5) flat arrangement of tumor cells, (6) poor preservation of the cytoplasm and amphophilic cytoplasmic trails ("comet" cells), (7) inclusion cells ("phagocytosis"), (8) absence of tumor diathesis. Hence in contrasting the endometrial stromal sarcoma from other neoplasms in the uterine corpus, (see Table 1), the differences are not fully recognized. The present case was diagnosed as such because of following features: isolated tumor cells, uniform pattern appearance of tumor cells, poor preservation of the cytoplasm, absence of tumor diathesis on imprint smears and absence of any organoid structures in histological sections.

In an undifferentiated endometrial carcinoma electron-microscopy indicated that most poorly differentiated and undifferentiated carcinoma of endometrium caused abortive glandular lumen formation or intracytoplasmic neolumen formation and perinuclear microfilaments running in concentric bundles ${ }^{1,4)}$. 
The tumor cells seem to produce the basal lamina. In our case, few tumor cells occurred in small clumps in imprint smears and intracytoplasmic bundles of microfilaments were observed on rare occasions. In these tumor cells basal lamina is not found. These findings support the diagnosis of undifferentiated endometrial carcinoma. Intracytoplasmic microfilaments are also found in various epithelial and stromal neoplasms ${ }^{8)}$, and in addition desmosome-like junctions observed in endometrial stromal sarcoma ${ }^{2)}$. Hence it is difficult to define clearly the histogenetic nature of tumors in some cases.

Regarding endometrial stromal sarcoma:Kempson $^{7)}$ reported that impregnation of reticulin fibers running between cells in the sarcoma is useful for the differentiation between endometrial stromal sarcoma and cervical undifferentiated carcinoma. The endolymphatic invasion is found only in a few endometrial stromal sarcomas. Presently, there is no marker for endometrial stromal sarcomas. One report stated that areas of epithelial differentiation are present in about one-quarter of endometrial stromal tumors of all types ${ }^{3)}$.

One report suggests that prospective cytodiagnosis of uterine sarcoma is possible ${ }^{5)}$. References mentioned support the cytological monomorphous pattern found in our case, thus other cytodiagnosis features were not similar. Further conclusions must be drawn upon additional cases.

\section{Summary}

Cytodiagnosis of the case reported was diagnosed as endometrial stromal sarcoma. Cytological features found included isolated tumor cells, monomorphous pattern of tumor cells, "comet" cells and the absence of tumor diathesis. Further these features may be useful for the cytodiagnosis of endometrial stromal sarcoma.

\section{References}

1) Akashi, E. : The ultrastructural studies on the human endometrial carcinoma, Acta Obstet. Gynaec. Jap., $25: 781 \sim 788,1973$.

2) Akhtar, M., Kim, Ph.Y. and Young, I. : Ultrastructure of endometrial stromal sarcoma, Cancer, $35: 406$ $\sim 412,1975$.

3) Blaustein, A. : Pathology of the female genital tract, 376 382, Springer, New York, 1982.

4) Ferenczy, A. : The ultrastructural morphology of gynecologic neoplasms, Cancer, 38:463 486, 1976.

5) Höffken, H., Rummel, H.H. and Hoppe, L. : Uterine Sarkome, Fortschr. Med., 98:1365 1368, 1980.

6) Hsiu, J-G. and Stawicki, M.E. : The cytologic findings in two cases or stromal sarcoma of the uterus, Acta Cytologica, $23:$ 487 489, 1979.

7) Kempson, R.L. and Bari, W. : Uterine sarcomas, Human Pathology, $1: 331 \sim 349,1970$.

8) Llombart-Bosch, A., Peydro-Olaya and Gomar, F. : Ultrastructure of one Ewing's sarcoma of bone with endothelial character and a comparative review of the vessels in 27 cases of typical Ewing's sarcoma, Path. Res. Pract., $167: 71 \sim 87,1980$.

9) Riotton, G. and Christopherson, W.M. : Cytology of the female genital tract, 30, WHO, Geneva, 1973.

10) Takahashi, M. : Color atlas of cancer cytology, 234, Igaku-Shoin, Tokyo, 1981. 


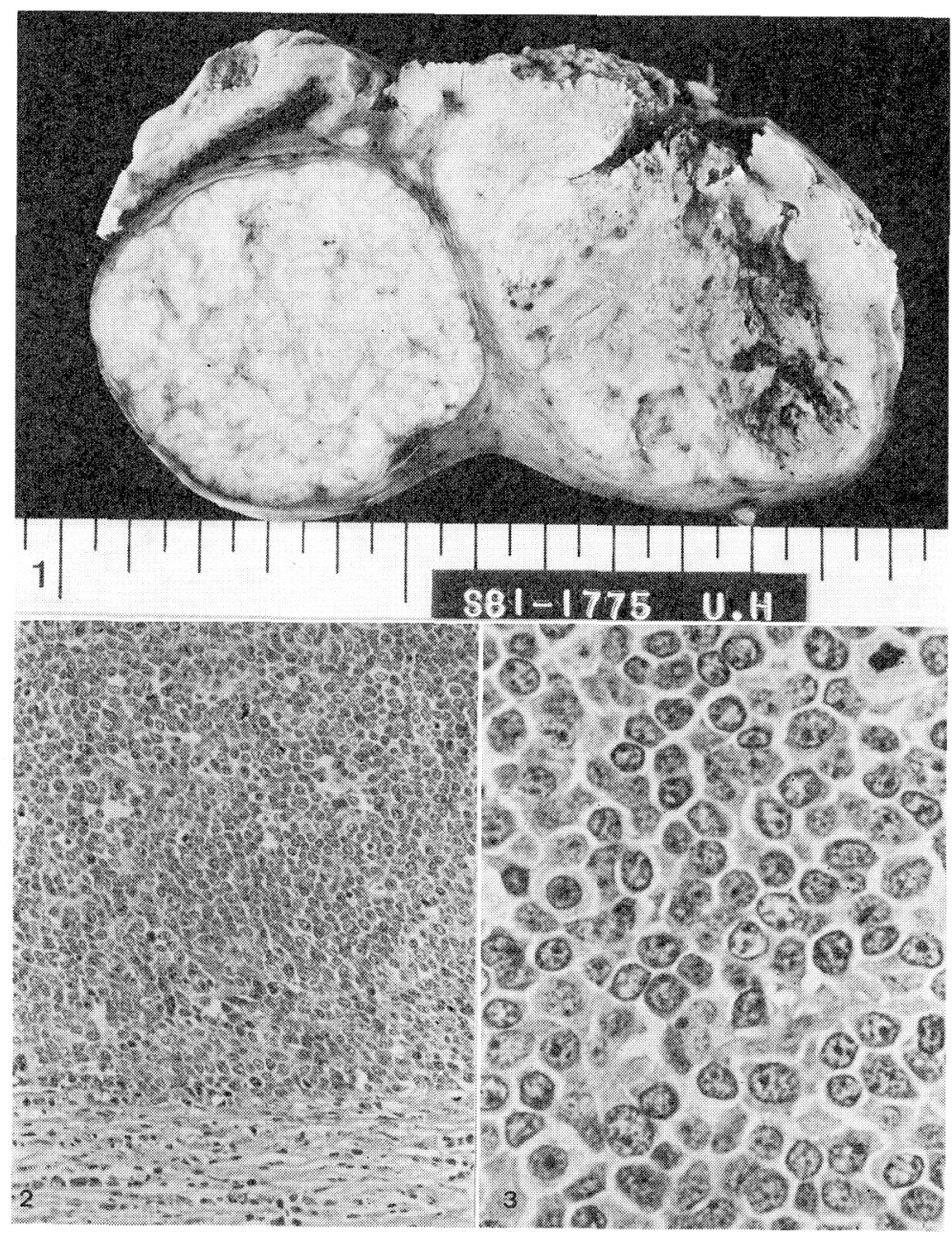

Fig. 1 The tumor on the right side is the sarcoma exhibiting central necrosis and almost complete myometrial demarcation. The sarcoma ruptures into the uterine cavity (upper part). The tumor on the left side is leiomyoma.

Fig. 2 The sarcomatous tissue is composed of uniform ovoid cells and shows the clear demarcation from the myometrium. HPS, $\times 100$.

Fig. 3 The sheets of uniform ovoid or round tumor cells with scant cytoplasm are observed and a mitotic figure is found in the upper right corner. HPS, $\times 400$. 


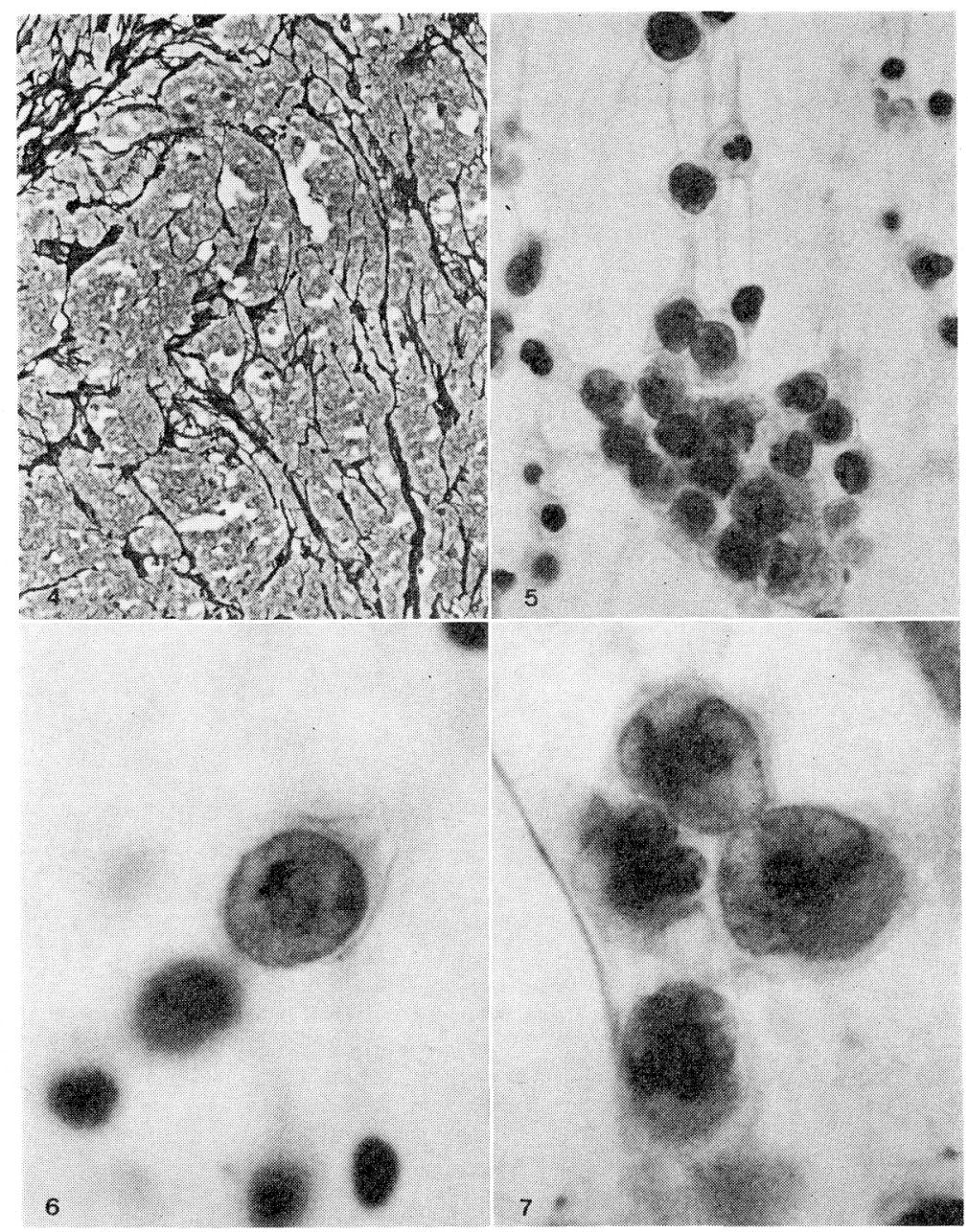

Fig. 4 Reticulin fibers do not run around individual tumor cells but create a net around cells. Reticulin stain, $\times 100$.

Fig. 5 A cluster of a few tumor cells is observed. Papanicoloau stain, $\times 400$.

Fig. 6 A round tumor cell with scant cytoplasm shows fine granular nuclear chromatins and a distinct nucleolus. The cytoplasm is slightly cyanophilic with indistinct cytoplasmic margin. Papanicolaou stain, $\times 1,000$.

Fig. 7 Two tumor cells with eccentric nucleus have a more abundant cytoplasm with strong basophilia (the dark spheroid). Papanicolaou stain, $\times 1,000$. 


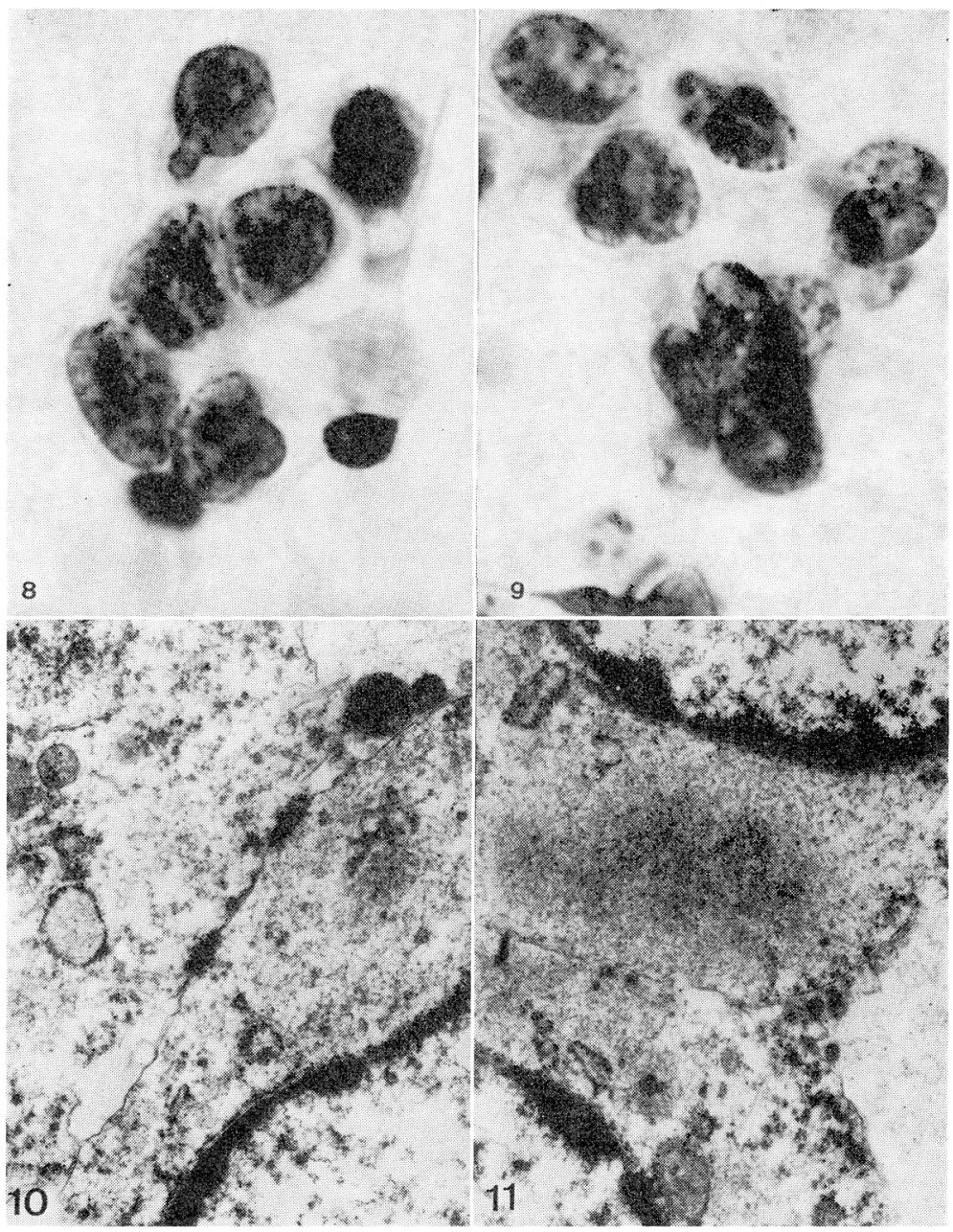

Fig. 8 A cluster of tumor cells with scant cytoplasm and irregular nuclei demonstrating a nipple-like projection and notched margins. Papanicolaou stain, $\times 1,000$.

Fig. 9 A giant cell with the bizarre nucleus is seen in a small cluster of cells. Papanicolaou stain, $\times 1,000$.

Fig.10 Two desmosome-like junctions are observed between two tumor cells. $\mathrm{U}-\mathrm{Pb}$ double stain, $\times 10,000$,

Fig.11 In two tumor cells microfilaments form a cytoplasmic sphere in the upper cell. U-Pb double stain, $\times 10,000$. 